\title{
EARLY PERMIAN PALAEOTEMPERATURE VALUES PROPOSED FOR CONTINENTAL RED-BED DEPOSITS OF THE TAMBACH FORMATION AT THE BROMACKER SECTION
}

\author{
F. Scholze, A. Pint \\ Friedrich Schiller University Jena, Jena, 07749 Germany
}

\begin{abstract}
A variety of formulas can be found in the literature to convert geochemical data into absolute palaeotemperatures. In the present study, we test a formula for calculating the Early Permian (Artinskian) palaeotemperatures based on major element values from continental red-bed deposits of the Tambach Sandstone Member (Tambach Formation, Rotliegend Group) in Germany. The geochemical data used herein were extracted from a previous study on the Bromacker section. Applying the literature-based dataset constitutes the first approach aimed to a better understanding of certain local palaeoclimate aspects (i.e., mean annual temperature) and can be easily expanded to wider stratigraphic and palaeogeographic ranges through future studies.
\end{abstract}

Keywords: Permian, Artinskian, Rotliegend, climate, temperature, red beds, Bromacker, Thuringian Forest

\section{Introduction}

Quarries, excavations, and drill cores at the Bromacker locality near TambachDietharz in the Thuringian Forest Mountains (Thuringia, Central Germany) expose the Early Permian (Artinskian) red-bed deposits of the Tambach Formation (Figs. 1, 2). The Bromacker outcrop section is a fossil lagerstätte $[1,2]$, which is famous for its contents of both tetrapod skeletons [3-5] and tetrapod trace fossils [6-9] (Fig. 3). Additionally, arthropods (i.e., conchostracans, myriapods, and insects), plant remains, and invertebrate ichnia occur frequently (e.g., [10-13]). The most common ichnia are Tambia spiralis Müller, 1969 [11, 14], Striatichnium bromackerense Martens, 1982 [15], Scoyenia gracilis White, 1929 [12], and some others [15], which are probably part of the characteristic continental Scoyenia ichnofacies [16, 17] indicating temporary restricted moist "wet red beds" [18] deposited on alluvial plains and floodplains. Previous sedimentological studies of the Bromacker section and adjacent outcrops of the Tambach Formation have been performed by several researchers (for details see [12, 19-22]); a list of fossils found at the Bromacker section has been compiled (see [2, 23]). In the present study, major element contents of fine-grained sedimentary rock samples from both surface and drill core sections at the Bromacker locality were used to calculate palaeotemperature values. The particular geochemical data were obtained from a previous publication authored by T. Martens and colleagues [20]. These data were converted into palaeotemperatures based on formulas established by N.D. Sheldon 


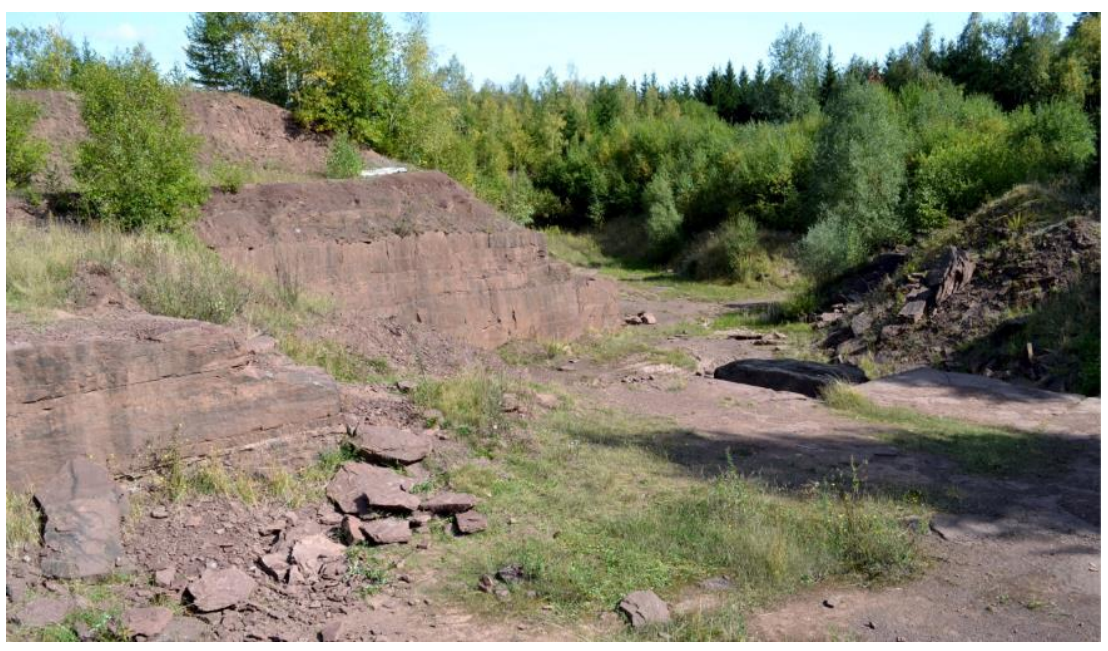

Fig. 1. Present day outcrop situation of the Tambach Sandstone Member (middle part of the Tambach Formation, Rotliegend Group; Artinskian, Early Permian) in a quarry section at the Bromacker locality (Thuringia, Central Germany)

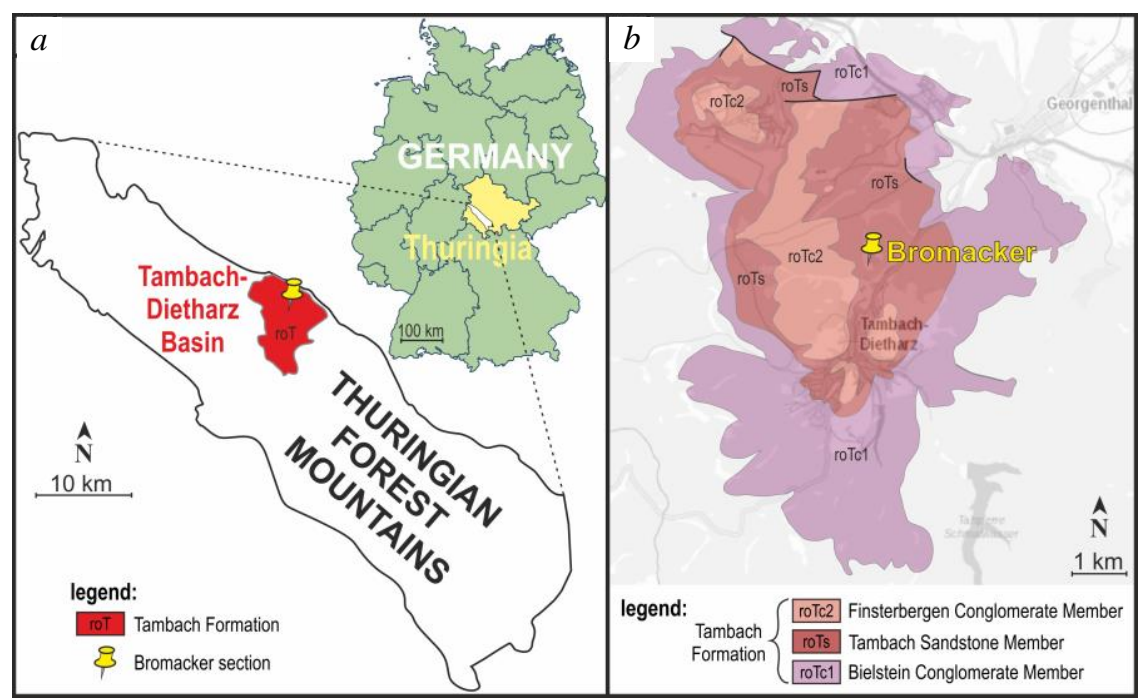

Fig. 2. Geographic position of the study area [28]. $a$ - Map of Germany presenting Thuringia and the Tambach-Dietharz Basin in the Thuringian Forest Mountains. $b$ - Geologic map of the Tambach-Dietharz Basin presenting the lithostratigraphic subdivision of the Tambach Formation into three units: the Bielstein Conglomerate Member (roTc1), the Tambach Sandstone Member (roTs), and the Finsterbergen Conglomerate Member (roTc2)

and colleagues $[24,25]$. The herein proposed absolute degree Celsius $\left({ }^{\circ} \mathrm{C}\right)$ values for the palaeotemperature at the time of sedimentation may serve as a basic regional contribution to further studies dealing with the Late Carboniferous-Early Permian palaeoclimatic conditions in general $[26,27]$. 


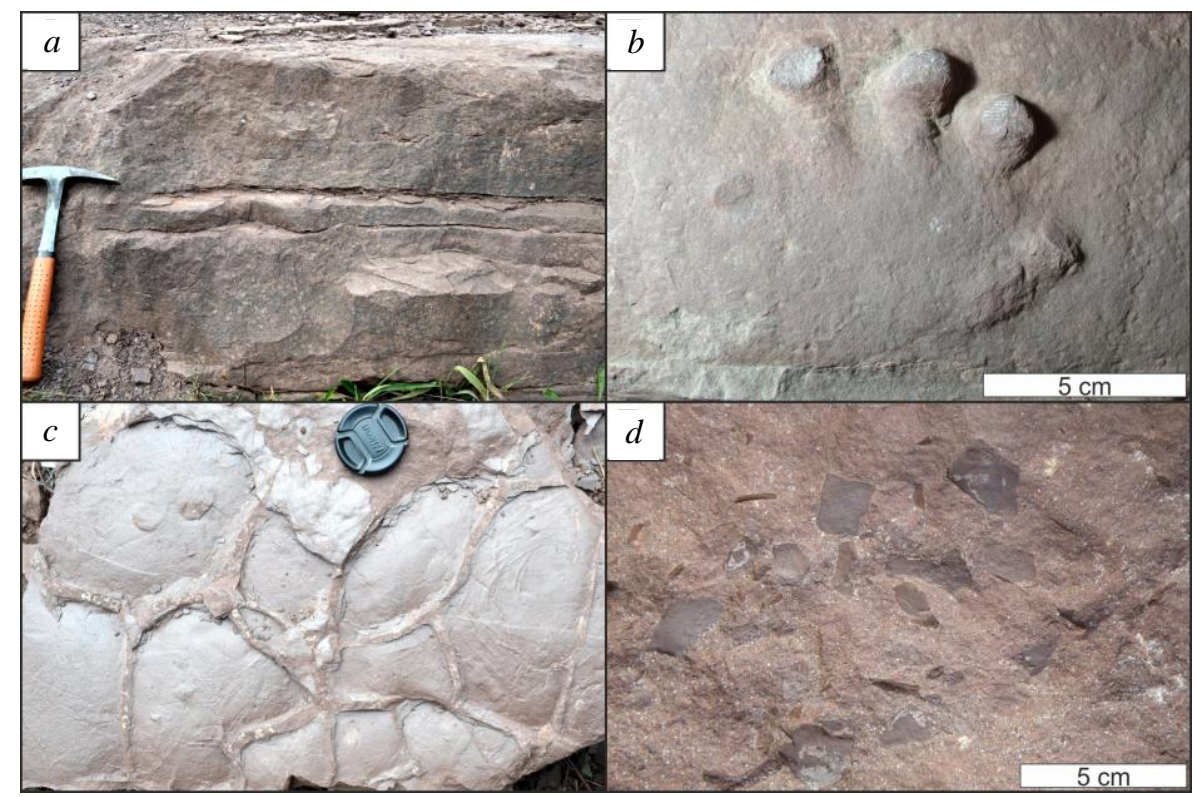

Fig. 3. Sedimentary structures and tetrapod trace fossils observed frequently in the Bromacker section (Tambach Sandstone Member; Artinskian, Early Permian): $a$ - Horizontal mudstone drapes in the sandstone bed; a 30-cm long hammer for scale; $b$ - tetrapod trace fossil identified as Ichniotherium sphaerodactylum (Pabst, 1895); $c$ - bottom view on the bedding plane showing desiccation cracks; 5 -cm lens cap for scale; $d$-intraformational clay-/siltstone rip-up clasts in a sandstone bedding plane

\section{Geologic Setting}

The Bromacker section is exposed by abandoned and active quarries, a scientific excavation, and shallow core drillings (Fig. 4), all located in an area about $2 \mathrm{~km}$ north to the city center of Tambach-Dietharz (Southern Thuringia, Central Germany). The Thuringian Forest Mountains belong to a tectonically uplifted block of the Variscan basement, which is affected by predominantly NW-SE trending faults and flexures. The Variscan basement is composed of various metamorphic rocks with plutonic intrusions, deeply incised or covered by the Late Carboniferous-Early Permian sediment fillings of the Thuringian Forest Basin that are nowadays widely exposed through surface outcrops in the Thuringian Forest Mountains. These sedimentary deposits, with in places intercalated acidic (rhyolitic) and mafic (doleritic) volcanic rocks, belong to the Gehren Subgroup and the Rotliegend Group, which can be further subdivided lithostratigraphically in multiple formations (see [28] for a detailed lithostratigraphy; see [29] for a high-resolution geochronology). The Tambach Formation at the Bromacker site bears a rich tetrapod and arthropod (i.e., conchostracan) fauna. According to J.W. Schneider and colleagues [30], these faunal elements are biostratigraphically indicative of the Artinskian (Cisuralian, Early Permian) age, although the Asselian [31] or Sakmarian [32] age has also been mentioned. The occurrences of Thuringothyris, Seymouria, Diadectes, and Tambachia in the Tambach Formation at the Bromacker section point to the Seymouran land-vertebrate faunachron [33], which is correlated with both the Wolfcampian Stage in North America and the global Artinskian Stage [30]. 


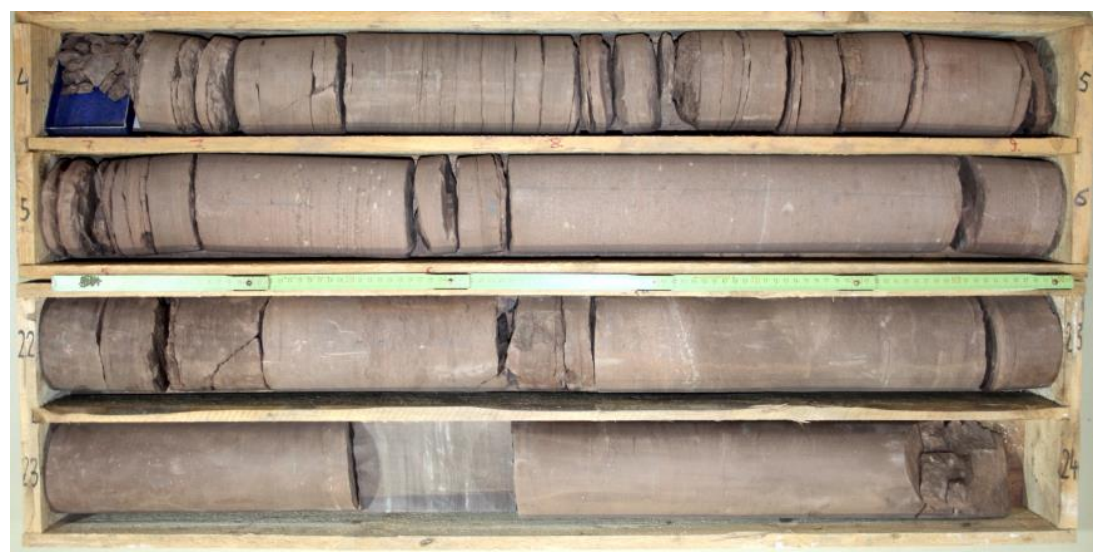

Fig. 4. Examples of the core boxes from the Bromacker FB2/2004 drill core section with finegrained siliciclastics from the Tambach Sandstone Member (depths 4-5 m, 22-24 m; scale bar in the centre is $1 \mathrm{~m}$ in length)

The area around Tambach-Dietharz belongs to a sedimentary basin, the so-called Tambach-Dietharz Basin, in which surface outcrops of the Tambach Formation extend $10 \mathrm{~km}$ from south to north and about $8 \mathrm{~km}$ from west to east (Fig. 2). This basin forms a small part of the superordinate Thuringian Forest Basin. The Bromacker section is situated in the centre of the Tambach-Dietharz Basin. Therein, the Tambach Formation is subdivided lithostratigraphically into three members in ascending order: the Bielstein Conglomerate (also designated as 'Lower Conglomerate'), the Tambach Sandstone, and the Finsterbergen Conglomerate (also designated as 'Upper Conglomerate') [28]. The Bielstein Conglomerate Member is a predominantly coarse-grained conglomerate composed of rhyolite debris, which are the erosional products of the directly adjacent Oberhof Rhyolite Complex that is flanking the Tambach-Dietharz Basin and wellexposed along the southwestern to southeastern margins of the latter. Here it is deposited in canyons that are locally incised into the underlying rhyolitic volcanites. In its proximal setting, the conglomerates were transported and deposited by wadi-like flash floods and debris flows, which towards the basin center gradually shift into conglomerates of smaller clast sizes deposited by braided rivers. The overlying Tambach Sandstone Member represents a more basinal facies, which yields a wide spectrum of lithologies, including cross-bedded and massive sandstones of highenergy fluvial channels. They often form decimeter- to meter-thick sandstone beds, which are separated horizontally by millimeters- to centimeters-thin mudstone drapes (Fig. 3, a) that can yield tetrapod trace fossils (Fig. 3, b). Desiccation cracks (Fig. 3, c), intraformational claystone rip-up clasts (Fig. 3, d), scour marks (Fig. 5, a), and, less frequently, ripples (Fig. 5, $b$ ) and millimeters to centimeters small-sized load casts (Fig. 5, c) are common. Additionally, the Tambach Sandstone Member of the Bromacker section also contains a few meters thick horizon of massive to partially laminated siltstone with predominantly horizontal bedding. This interval (the 'Bromacker Horizon' [20]) also includes claystone intraclasts-rich mudstones and weakly developed palaeosoil intervals of locally varying thickness. The palaeosoils can contain centimeter-small carbonate nodules; remains of fossil roots are locally frequent. The partially overlying Finsterbergen Conglomerate Member is generally finer-grained than 


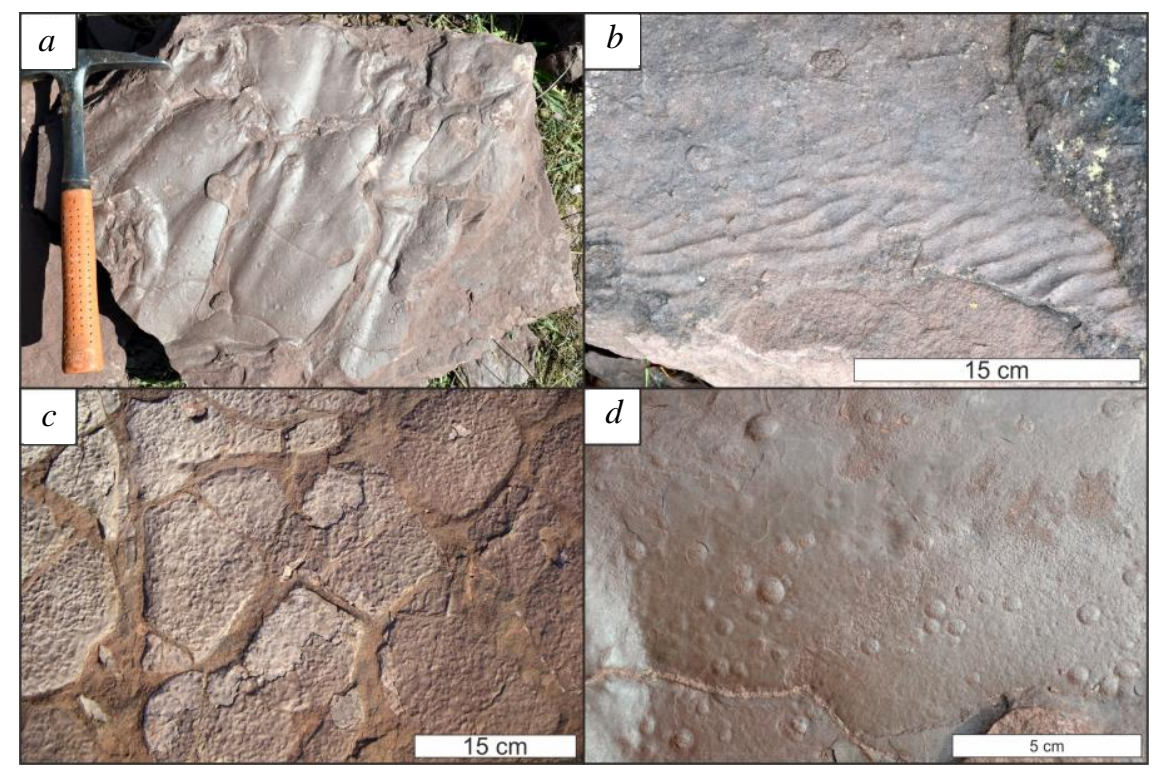

Fig. 5. Sedimentary structures observed on lose blocks in the present day Bromacker section (Tambach Sandstone Member; Artinskian, Early Permian): $a$ - scour marks on the bottom side of a sandstone bed; a 30-cm long hammer for scale; $b$ - ripples on a fine-grained sandstone surface; $c$ - numerous sub-centimeter small load casts on the bottom side of a fine-grained sandstone block, separated secondarily by desiccation cracks; $d$ - raindrop marks of various diameters

the Bielstein Conglomerate Member. The Finsterbergen Conglomerate Member is composed primarily of horizontally stratified, fine-grained conglomerates, which can be interpreted as deposits on alluvial braidplains. The Finsterbergen Conglomerate Member shows a polymictic composition that involves the clasts of granite, metamorphic quartz, and rhyolite, as well as, to some extent, the clasts of schist-/gneiss-like metamorphic rocks and mafic volcanites. Among them, particularly the granitic clasts indicate a change in the delivery area with the sediment coming from the more distant Ruhla Crystalline basement.

In general, the transitions of both the Bielstein Conglomerate Member-Tambach Sandstone Member and the Tambach Sandstone Member-Finsterbergen Conglomerate Member are gradual with the intervals composed of vertical and lateral intercalations of several meters-thick conglomerate and sandstone units. The rock color of the Tambach Formation is entirely red, with only some minor differentiations that can be made between purplish red (i.e., the Bielstein Conglomerate Member) and greenishgreyish colors in bleaching stains of millimeters to centimeters diameters within claystone/siltstone to fine-grained sandstones (i.e., the Tambach Sandstone Member).

\section{Materials and Methods}

The source data for this work were obtained from the study by T. Martens and colleagues [20] on major element contents of the Tambach Sandstone Member at the Bromacker section. Particularly, they investigated fine-grained siliciclastic rocks from three sections (see [20, tables 1,2]): a scientific excavation site, an active quarry, and the drill core Bromacker FB2/2004 (Fig. 4) (see [34] for coordinates of this drill 
core section). Among them, the content values of $\mathrm{Al}_{2} \mathrm{O}_{3}$ and $\mathrm{SiO}_{2}$ were selected and processed for subsequent palaeotemperature calculation, following the methodology described by N.D. Sheldon and N.J. Tabor [25]. As the first step, the $\mathrm{Al}_{2} \mathrm{O}_{3}$ and $\mathrm{SiO}_{2}$ values were converted into the molar masses of $\mathrm{Al}$ and $\mathrm{Si}$, respectively. Secondly, the "clayness" $(=\mathrm{C})$ was calculated according to the formula provided by N.D. Sheldon and N.J. Tabor [25]: $\mathrm{C}=\mathrm{Al} / \mathrm{Si}$. Finally, the palaeotemperature $(=\mathrm{T})$ in ${ }^{\circ} \mathrm{C}$ was calculated (according to $[25$, p. 16]) as follows: $\mathrm{T}=46.9 \cdot \mathrm{C}+4$, whereby the empirical accuracy of the $\mathrm{T}$ values is $\pm 0.6{ }^{\circ} \mathrm{C}$. The resulting values represent mean annual temperature values. The $\mathrm{T}$ values reflect the local temperature at the time of the sediment deposition.

\section{Results}

The results of the present study are given in Table 1. The contents of major element oxides from fine-grained siliciclastics of the Tambach Formation (Tambach Sandstone Member) at the Bromacker section were derived as multiple measurement values (15 from the excavation site, 9 from the active quarry, 28 from the Bromacker FB2/2004 drill core section; for details see [20, table 1]) and from another set of seven rock samples (see [20, table 2]). Their original sample numbers given by T. Martens and colleagues [20] were maintained in the present study. Following N.D. Sheldon and N.J. Tabor [25, table 4], the molecular masses of 101.96 and $60.09 \mathrm{~g} / \mathrm{mol}$ for $\mathrm{Al}_{2} \mathrm{O}_{3}$ and $\mathrm{SiO}_{2}$, respectively, were used for converting the respective oxides [20] into molars (i.e., Al instead of $\mathrm{Al}_{2} \mathrm{O}_{3} ; \mathrm{Si}$ instead of $\mathrm{SiO}_{2}$ ). The resulting $\mathrm{T}$ values range between $10.9^{\circ} \mathrm{C}$ and $15.0^{\circ} \mathrm{C}$ (Table 1). Their average value is $12.7^{\circ} \mathrm{C}$.

Table 1. Calculation of the palaeotemperature values based on major element data from the analyses of fine-grained red-bed deposits of the Tambach Sandstone Member (Tambach Formation, Early Permian) of the Bromacker section (Thuringian Forest Basin, Germany). The oxide contents and sample numbers given according to T. Martens and colleagues (see [20, therein tables 1, 2])

\begin{tabular}{|c|c|c|c|c|c|c|c|c|c|c|c|}
\hline & \multicolumn{10}{|c|}{ Sample number } \\
\hline & & 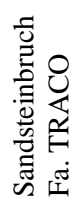 & 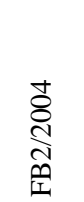 & 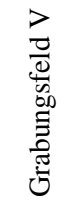 & $\begin{array}{l}\text { I } \\
\dot{I} \\
\stackrel{1}{1} \\
\text { ô. }\end{array}$ & 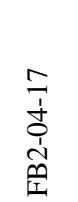 & $\begin{array}{l}\stackrel{\infty}{\sim} \\
\stackrel{+}{+} \\
\stackrel{1}{\sim} \\
\text { DิI }\end{array}$ & $\begin{array}{l}\vec{j} \\
\stackrel{+}{1} \\
\stackrel{2}{\partial}\end{array}$ & $\begin{array}{l}\frac{1}{5} \\
\frac{1}{2} \\
\frac{2}{2}\end{array}$ & 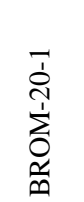 & $\begin{array}{l}\stackrel{1}{1} \\
\stackrel{1}{2} \\
\sum_{0}^{1} \\
0 \\
\frac{1}{\infty}\end{array}$ \\
\hline \multirow{2}{*}{$\begin{array}{l}\text { Oxide } \\
\text { contents }\end{array}$} & $\begin{array}{c}\mathrm{SiO}_{2} \\
\text { [in weight-\%] }\end{array}$ & 52.6 & 59.4 & 58.5 & 54.2 & 60.9 & 64.1 & 59.7 & 57.1 & 57.1 & 53.8 \\
\hline & $\begin{array}{c}\mathrm{Al}_{2} \mathrm{O}_{3} \\
\text { [in weight-\%] }\end{array}$ & 21 & 16.9 & 17.5 & 19.5 & 15.4 & 16.1 & 17.5 & 17.8 & 18.7 & 20.5 \\
\hline \multirow{2}{*}{ Molar mass } & Si [in molars] & 0.875 & 0.989 & 0.974 & 0.902 & 1.013 & 1.067 & 0.994 & 0.950 & 0.950 & 0.895 \\
\hline & $\mathrm{Al}$ [in molars] & 0.206 & 0.166 & 0.172 & 0.191 & 0.151 & 0.158 & 0.172 & 0.175 & 0.183 & 0.201 \\
\hline Clayness (C) & $\mathrm{C}=\mathrm{Al} / \mathrm{Si}$ & 0.24 & 0.17 & 0.18 & 0.21 & 0.15 & 0.15 & 0.17 & 0.18 & 0.19 & 0.22 \\
\hline $\begin{array}{l}\text { Palaeotempe- } \\
\text { rature }(\mathrm{T})\end{array}$ & $\begin{array}{c}\mathrm{T}=46.9 \cdot \mathrm{C}+4 \\
{\left[\text { in }{ }^{\circ} \mathrm{C}\right]}\end{array}$ & 15.0 & 11.9 & 12.3 & 13.9 & 11.0 & 10.9 & 12.1 & 12.6 & 13.1 & 14.5 \\
\hline
\end{tabular}

\section{Discussion}

The calculated temperature values of $10.9-15.0^{\circ} \mathrm{C}\left(12.7^{\circ} \mathrm{C}\right.$ on average $)$ are proposed to reflect a mean annual temperature during the deposition of the Tambach 
Sandstone Member (middle part of the Tambach Formation; Rotliegend Group; Artinskian, Early Permian) at the Bromacker section. According to N.D. Sheldon and N.J. Tabor [25, p. 16], the formula used for the palaeotemperature calculation applies to inceptisols, which is the immature type of modern and fossil soil that can often be found on mountain slopes. Basically, distinctive immaturity of inceptisols corresponds to a weak degree of palaeopedogenesis that can be generally observed in the Bromacker section; however, the palaeosoil from the Bromacker section cannot be determined as an inceptisol sensu stricto. Instead, this interval of the Tambach Sandstone Member is designated as a palaeopedogenic poorly developed, immature ('inceptisol-like') palaeosoil that is characterized by high sedimentation rates, whereas the latter prevented a mature palaeosoil formation. On the contrary, some characteristic features of vertisols can also be observed at the Bromacker section, such as alternating drying up and wet phases indicated by frequent desiccation cracks and rooting, respectively. However, pronounced swelling and shrinking of clay minerals and the resulting destruction of the primary sedimentary bedding in vertisols are not characteristic of the immature type of palaeosoil in the Bromacker section. Consequently, the inceptisol-based formula proposed by N.D. Sheldon and N.J. Tabor [25] was applied to the palaeosoil interval of the Tambach Sandstone Member at the Bromacker section to test the palaeotemperature calculation.

Compared to the literature data, the herein calculated palaeotemperature values are lower than the proposed palaeotemperature of $29-34^{\circ} \mathrm{C}$, which was calculated from oxygen isotopes values measured in marine brachiopod shells from the Early Permian (Artinskian) in the Southern Urals region [35, p. 346]. The latter corresponds to a seawater palaeotemperature, whereas the Bromacker palaeotemperature values account for a continental hinterland realm. The regional differences in the palaeotemperature might reflect palaeo-latitudinal effects that can result in the decreasing palaeotemperatures from low latitudes towards high latitudes [36]. Further, the comparability between isotopic-based and major element-based palaeothermometers must be viewed critically. Although both the Bromacker section (the present study) and the Southern Urals [35] are dated to the Artinskian age, it should also be considered that the calculated lower palaeotemperature values for the Bromacker section were strongly controlled by the local palaeoenvironmental conditions in contrast to the seawater palaeotemperature. In particular, a continental hinterland realm might have been more intensively affected by its palaeolandscape morphology (i.e., variation in altitude), locally varying solar radiation, airflow temperatures, and humidity, as well as palaeotemperature variations. Consequently, multiple aspects of litho- and biofacies should be discussed regarding both the Tambach Formation in detail and the Rotliegend Group in general in order to better understand the palaeoenvironmental gradients in the continental realm.

The succession of the Rotliegend Group of the Thuringian Forest Basin represents a variety of alluvial, fluvial, and lacustrine sedimentary rocks, all deposited in an intramontaneous region that was likely located far distant from any palaeogeographic coastline. The changes of the sediment rock color within the Rotliegend Group from grey at its base towards red at its top reflect a general aridization trend [26]. The deposits of the Rotliegend Group in the Thuringian Forest Basin represent this increasing aridization by a change from the semi-humid to semi-arid conditions, whereas this trend was 
temporarily interrupted by a few wet phases [26]. In the study area, this can be observed by the records of grey colored, laminated, and fine-grained lacustrine deposits of the Oberhof Formation in the Leinagrund valley (Wintersbrunnen section; e.g., see [37]) at the margin of the Tambach-Dietharz Basin, whereas in other sections of the Thuringian Forest Mountains the red colored playa-facial sediments of the Rotterode Formation clearly indicate a shift in the palaeoclimate to more semi-arid conditions [26, 38]. The depositional setting of the overlying Tambach Formation was characterized by D.A. Eberth and his colleagues [21] as a small, drainless upland basin; however, a pronounced inland character of the sedimentary facies was not described in detail. Temporary heavy rainfall [39] may have triggered the deposition of massive to horizontally bedded sandstone beds. In contrast, the frequently observed cross-bedded, channel-shaped sandstones indicate braided river environments (e.g., [38, p. 136]). The predominantly clayey and silty interval ('Bromacker Horizon 1', see [2, fig. 16]) of the Tambach Sandstone Member at the Bromacker section can be interpreted as resulting from the intensive run-off through mud flows [38]. The frequent occurrences of both desiccation cracks (Fig. 3,c) and raindrop marks (Fig. 5,d) on the claystone and siltstone bedding planes indicate periodic, at times, heavy precipitation [12]. Locally resulting ephemeral freshwater ponds were formed during intervals between precipitation and evaporation, which favored the temporary living conditions of conchostracans [13] and jellyfish [40]. A successive dry out led to the palaeopedogenic overprinting processes resulting in a formation of immature, inceptisol-like palaeosoils. The occurrences of predominantly reptile-like tetrapods, as well as the records of tetrapod ichnia (e.g., Megatambichnus [41]), in the Tambach Sandstone Member indicate the pronounced terrestrial conditions [23]. The flora of the Bromacker section contains mainly cones of calamites and fronds of xerophilic conifers, which were also adapted to drought [10]. The water level marks (evaporation marks; e.g., see [21, fig. 5c]) and some other sedimentary structures, interpreted either as ice crystal marks [19, plate XIV] or as presumed ice layer marks [22], support the assumptions on possible daily palaeotemperature variations, which also involves temporary frost conditions during night.

\section{Conclusions}

It is well-known that the global paleoclimate at the end of the Late Palaeozoic is characterized by the increase in aridization during the Early Permian-Middle Permian [42]. This aridization, temporarily interrupted by several wet phases, is also recorded in the continental sedimentary rocks of the Rotliegend Group in Western and Central Europe [26]. In order to better understand the local palaeoclimate conditions of this time span, values of $10.9-15.0^{\circ} \mathrm{C}\left(12.7^{\circ} \mathrm{C}\right.$ on average) are proposed to reflect the mean annual palaeotemperature for the Tambach Sandstone Member at the Bromacker section. The present interdisciplinary study hopefully will promote the ongoing discussions on the Early Permian palaeoclimate proxies for the Rotliegend Group in Europe. The locally prevailed palaeoenvironmental conditions during the inland red-bed deposition, such as the gradients in altitude or the temporary (periodic?) changes in both humidity and temperature, may best explain a deviation from the Early Permian seawater palaeotemperatures that were calculated previously [35] by using oxygen isotope palaeothermometers. Calculating palaeotemperatures based on major element contents of palaeosoils, by using a variety of published formulas from 
the literature $[24,25,43]$, bears a high potential for successive studies. Palaeosoil data from other red-bed deposits [44-46] of a broader Permian time span should become integrated in order to better understand the palaeoclimate evolution in the continental realm.

Acknowledgements. The Bromacker Project is a cooperation of the Museum für Naturkunde Berlin, the Stiftung Schloss Friedenstein Gotha, the Geopark Thüringen Inselsberg-Drei Gleichen, and the Friedrich-Schiller Universität Jena. Our studies are funded by the Federal Ministry of Education and Research, Germany (BMBF, grant 'Bromacker Project').

We are very thankful to Thomas Martens for guiding the joint field trips to the important outcrop sections around Tambach-Dietharz. Many thanks to Joerg W. Schneider, Sebastian Voigt, and Birgit Gaitzsch for providing data on the tetrapod trace fossil that is shown in Fig. 3, $b$. Joerg W. Schneider is kindly acknowledged for his review that improved this publication.

\section{References}

1. Martens T. Ursaurierlagerstätte Bromacker. In: Klassische Fundstellen der Paläontologie. Bd. IV. Korb, Goldschneck Verlag, 2001, S. 51-61. (In German)

2. Martens T. Scientific Importance of the Fossillagerstätte Bromacker (Germany, Tambach Formation, Lower Permian) - Vertebrate Fossils. Göttingen, Cuvillier, 2018. 54 p.

3. Berman D.S., Henrici A.C., Sumida S.S., Martens T. Redescription of Seymouria sanjuanensis (Seymouriamorpha) from the Lower Permian of Germany based on complete, mature specimens with a discussion of paleoecology of the Bromacker locality assemblage. J. Vertebr. Paleontol., 2000, vol. 20, no. 2, pp. 253-268. doi: 10.1671/02724634(2000)020[0253:ROSSSF]2.0.CO;2.

4. Berman D.S., Reisz R.R., Martens T., Henrici A.C. A new species of Dimetrodon (Synapsida: Sphenacodontidae) from the Lower Permian of Germany records first occurrence of genus outside of North America. Can. J. Earth Sci., 2001, vol. 38, no. 5, pp. 803-812. doi: 10.1139/e00-106.

5. Berman D.S., Henrici A.C., Kissel R.A., Sumida S.S., Martens T. A new diadectid (Diadectomorpha), Orobates pabsti, from the Early Permian of Central Germany. Bull. Carnegie Mus. Nat. Hist., 2004, vol. 35, pp. 1-36. doi: 10.2992/0145-9058(2004)35[1:ANDDOP]2.0.CO;2.

6. Pabst W. Über im Besitz des Herzoglichen Museums in Gotha befindliche Thierfährten aus dem Rothliegenden von Friedrichroda, Tambach und Kabarz in Thüringen.. Z. Dtsch Geol. Ges., 1895, Bd. 47, H. 3, S. 570-576. (In German)

7. Voigt S., Haubold H. Analyse zur Variabilität der Tetrapodenfährte Ichniotherium cottae aus dem Tambacher Sandstein (Rotliegend, Unter-Perm, Thüringen). Hallesches Jahrb. Geowiss., B, 2000, Bd. 22, S. 17-58. (In German)

8. Voigt S. Zur Geschichte der Tetrapodenfährtenfunde in den Sandsteinbrüchen bei TambachDietharz (1887-1908). Abh. Ber. Mus. Nat. Gotha, 2002, Bd. 22, S. 47-58. (In German)

9. Voigt S., Berman D.S., Henrici A.C. First well-established track-trackmaker association of paleozoic tetrapods based on Ichniotherium trackways and diadectid skeletons from the Lower Permian of Germany. J. Vertebr. Paleontol., 2007, vol. 27, no. 3, pp. 553-570. doi: 10.1671/0272-4634(2007)27[553:FWTAOP]2.0.CO;2. 
10. Barthel M., Rößler R. Calamiten aus dem Oberrotliegend des Thüringer Waldes. - Was ist "Walchia imbricata"? Veroeff. Naturhist. Mus. Schleusingen, 1994, Bd. 9, S. 69-80. (In German)

11. Müller A.H. Über ein neues Ichnogenus (Tambia n.g.) und andere Problematica aus dem Rotliegenden (Unterperm) von Thüringen. Monatsber. Dtsch. Akad. Wiss. Berlin, 1969, Bd. 11, no. 11/12, S. 922-931. (In German)

12. Martens T., Schneider J., Walter H. Zur Paläontologie und Genese fossilführender Rotsedimente - Der Tambacher Sandstein, Oberrotliegendes, Thüringer Wald. Freiberg. Forschungsh. C, 1981, Bd. 363, S. 75-100. (In German)

13. Martens T. Zur Taxonomie und Biostratigraphie der Conchostraca (Phyllopoda, Crustacea) des Jungpaläozoikums der DDR, Teil I. Freiberg. Forschungsh. C, 1983, Bd. 382, S. 7-105. (In German)

14. Müller A.H. Über problematische Lebensspuren aus dem Rotliegenden von Thüringen. Ber. Geol. Ges. D. D. R. Gesamtgeb. Geol. Wiss., 1956, Bd. 1, S. 147-154. (In German)

15. Martens T. Zur Stratigraphie, Taxonomie, Ökologie und Klimaentwicklung des Oberrotliegenden (Unteres Perm) im Thüringer Wald (DDR). Abh. Ber. Mus. Nat. Gotha, 1982, Bd. 11, S. 33-57. (In German)

16. Seilacher A. Bathymetry of trace fossils. Mar. Geol., 1967, vol. 5, nos. 5-6, pp. 413-428. doi: 10.1016/0025-3227(67)90051-5.

17. Buatois L.A., Mángano M.G. Invertebrate ichnology of continental freshwater environments. In: Miller W., III (Ed.) Trace Fossils. Concepts. Problems. Prospects. Ch. 17. Amsterdam, Elsevier, 2007, pp. 285-323. doi: 10.1016/B978-044452949-7/50143-1.

18. Schneider J.W., Voigt S., Lucas S.G., Rößler R. Late Palaeozoic wet red beds - dry red beds: How to distinguish them. XVIII Int. Congr. on the Carboniferous and Permian. Aug. 11-15, 2015, Kazan, Russia. Abstracts Volume. Kazan, Kazan Univ. Press, 2015, p. 169.

19. Lützner H. Sedimentation der variszischen Molasse im Thüringer Wald. Schriftenr. Geol. Wiss., 1981, Bd. 17, S. 1-217. (In German)

20. Martens T., Hahne K., Naumann R. Lithostratigraphie, Taphofazies und Geochemie des Tambach-Sandsteins im Typusgebiet der Tambach-Formation (Thüringer Wald, Oberrotliegend, Unteres Perm). Z. Geol. Wiss., 2009, vol. 37, no. 1/2, S. 81-119. (In German)

21. Eberth D.A., Berman D., Sumida S.S., Hopf H. Lower Permian terrestrial paleoenvironments and vertebrate paleoecology of the Tambach basin (Thuringia, Central Germany): The upland holy grail. Palaios, 2000, vol. 15, no. 4, pp. 293-313. doi: 10.1669/08831351(2000)015<0293:LPTPAV>2.0.CO;2.

22. Martens T. Die Bedeutung der Sedimentmarken für die Analyse der Klimaelemente im kontinentalen Unterperm. Z. Geol. Wiss., 2007, Bd. 35, N. 3, S. 177-211. (In German)

23. Martens T., Berman D.S., Henrici A.C., Sumida S.S. The Bromacker quarry -The most important locality of Lower Permian terrestrial vertebrate fossils outside of North America. N. M. Mus. Nat. Hist. Sci. Bull., 2005, no. 30, pp. 214-215.

24. Sheldon N.D., Retallack G.J., Tanaka, S. Geochemical climofunctions from North American soils and application to paleosols across the Eocene-Oligocene boundary in Oregon. J. Geol., 2002, vol. 110, no. 6, pp. 687-696. doi: 10.1086/342865.

25. Sheldon N.D., Tabor N.J. Quantitative paleoenvironmental and paleoclimatic reconstruction using paleosols. Earth-Sci. Rev., 2009, vol. 95, nos. 1-2, pp. 1-52. doi: 10.1016/j.earscirev.2009.03.004.

26. Roscher M., Schneider J.W. Permo-Carboniferous climate: Early Pennsylvanian to Late Permian climate development of central Europe in a regional and global context. Geol. Soc., London, Spec. Publ., 2006, vol. 265, pp. 95-136. doi: 10.1144/GSL.SP.2006.265.01.05. 
27. Paul J. Das Klima des Rotliegend. In: Stratigraphie von Deutschland X. Rotliegend. T. I: Innervariscische Becken. Schriftenreihe der Deutschen Gesellschaft für Geowissenschaften. Dtsch. Stratigr. Komm., 2012, H. 61, S. 731-742. doi: 10.1127/sdgg/61/2012/731. (In German)

28. Lützner H., Andreas D., Schneider J.W., Voigt S., Werneburg R. Stefan und Rotliegend im Thüringer Wald und seiner Umgebung. In: Stratigraphie von Deutschland X. Rotliegend. T. I: Innervariscische Becken. Schriftenreihe der Deutschen Gesellschaft für Geowissenschaften. Dtsch. Stratigr. Komm., 2012, H. 61, S. 418-487. doi: 10.1127/sdgg/61/2012/418. (In German)

29. Lützner H., Tichomirowa M., Käßner A., Gaupp R. Latest Carboniferous to early Permian volcano-stratigraphic evolution in Central Europe: U-Pb CA-ID-TIMS ages of volcanic rocks in the Thuringian Forest Basin (Germany). Int. J. Earth Sci., 2021, vol. 110, pp. 377-398. doi: 10.1007/s00531-020-01957-y.

30. Schneider J.W., Lucas S.G., Scholze F., Voigt S., Marchetti L., Klein H., Opluštil S., Werneburg R., Golubev V.K., Barrick J.E., Nemyrovska T., Ronchi A., Day M.O., Silantiev V.V., Rößler R., Saber H., Linnemann U., Zharinova V., Shen S.-Z. Late Paleozoic-early Mesozoic continental biostratigraphy - links to the Standard Global Chronostratigraphic Scale. Palaeoworld, 2020, vol. 29, no. 2, pp. 186-238. doi: 10.1016/j.palwor.2019.09.001.

31. Berman D.S., Reisz R.R., Scott D., Henrici A.C., Sumida S.S., Martens T. Early Permian bipedal reptile. Science, 2000, vol. 290, no. 5493, pp. 969-972. doi: 10.1126/science.290.5493.969.

32. Martens T. Biostratigraphie der Conchostraca (Branchiopoda, Crustacea) des Rotliegend. In: Stratigraphie von Deutschland X. Rotliegend. T. I: Innervariscische Becken. Schriftenreihe der Deutschen Gesellschaft für Geowissenschaften. Dtsch. Stratigr. Komm., 2012, H. 61, S. 98-109. doi: 10.1127/sdgg/61/2012/98. (In German)

33. Lucas S.G. Permian tetrapod faunachrons. N. M. Mus. Nat. Hist. Sci. Bull., 2005, no. 30, pp. 197-201.

34. Krause T., Martens T., Gores G. Die Forschungsbohrungen Bromacker 1/2004, Bromacker 2/2004 und Altenbergen 1/2005 im Gebiet zwischen Bromacker und Kandelaber bei Tambach-Dietharz - Zielstellung, technische Arbeiten und erste Ergebnisse. Abh. Ber. Mus. Nat. Gotha, 2006, Bd. 24, S. 199-202. (In German)

35. Korte C., Jasper T., Kozur H.W., Veizer J. $\delta^{18} \mathrm{O}$ and $\delta^{13} \mathrm{C}$ of Permian brachiopods: A record of seawater evolution and continental glaciation. Palaeogeogr., Palaeoclimatol., Palaeoecol., 2005, vol. 224, no. 4, pp. 333-351. doi: 10.1016/j.palaeo.2005.03.015.

36. Yang J., Cawood P.A., Du Y., Feng B., Yan J. Global continental weathering trends across the Early Permian glacial to postglacial transition: Correlating high- and low-paleolatitude sedimentary records. Geology, 2014, vol. 42, no. 10, pp. 835-838. doi: 10.1130/G35892.1.

37. Schulz M., Schneider J.W., Rößler R. Permian laminites - a key for palaeoenvironmental reconstruction. GeoBonn 2018 - Living Earth, 2-6 Sept. 2018, Bonn, Germany: Abstracts. Leipzig, F\&U Confirm, 2018, p. 216.

38. Schneider J. Biostratigraphie des kontinentalen Oberkarbon und Perm im Thüringer Wald, SW-Saale-Senke - Stand und Probleme. Beitr. Geol. Thueringen, Neue Folge, 1996, Bd. 3, S. 121-151. (In German)

39. Schneider J., Gebhardt U. Litho- und Biofaziesmuster in intra- und extramontanen Senken des Rotliegend (Perm, Nord- und Ostdeutschland). Geol. Jahrb. A, 1993, Bd. 131, S. 57-98. (In German)

40. Voigt S. Erstnachweis von fossilen Hydromedusen aus dem Tambacher Sandstein (Rotliegend, Unteres Perm, Thüringen). Freiberg. Forschungsh. C, 2002, Bd. 497, S. 45-57. (In German) 
41. Martens T. First burrow casts of tetrapod origin from the Lower Permian (Tambach Formation) in Germany. N. M. Mus. Nat. Hist. Sci. Bull., 2005, no. 30, p. 207.

42. Shi G.R., Waterhouse J.B. Late Palaeozoic global changes affecting high-latitude environments and biotas: An introduction. Palaeogeogr., Palaeoclimatol., Palaeoecol., 2010, vol. 298, nos. 1-2, pp. 1-16. doi: 10.1016/j.palaeo.2010.07.021.

43. Cao Y., Song H., Algeo T.J., Chu D., Du Y., Tian L., Wang Y., Tong J. Intensified chemical weathering during the Permian-Triassic transition recorded in terrestrial and marine successions. Palaeogeogr., Palaeoclimatol., Palaeoecol., 2019, vol. 519, pp. 166-177. doi: 10.1016/j.palaeo.2018.06.012.

44. Schneider J.W., Körner F., Roscher M., Kroner U. Permian climate development in the northern peri-Tethys area - the Lodève basin, French Massif Central, compared in a European and global context. Palaeogeogr., Palaeoclimatol., Palaeoecol., 2006, vol. 240, nos. 1-2, pp. 161-183. doi: 10.1016/j.palaeo.2006.03.057.

45. Luthardt L., Rößler R., Schneider J.W. Palaeoclimatic and site-specific conditions in the early Permian fossil forest of Chemnitz - sedimentological, geochemical and palaeobotanical evidence. Palaeogeogr., Palaeoclimatol., Palaeoecol., 2016, vol. 441, no. 4, pp. 627-652. doi: 10.1016/j.palaeo.2015.10.015.

46. Mouraviev F.A., Arefiev M.P., Silantiev V.V., Eskin A.A., Kropotova T.V. Paleosols and host rocks from the Middle-Upper Permian reference section of the Kazan Volga region, Russia: A case study. Palaeoworld, 2020, vol. 29, no. 2, pp. 405-425. doi: 10.1016/j.palwor.2019.05.004.

Received

June 24, 2021

Scholze Frank, Doctor of Science, Research Fellow, Institute of Geosciences, General and Historical Geology

Friedrich Schiller University Jena

Burgweg 11, Jena, 07749 Germany

E-mail:frank.scholze@uni-jena.de

Pint Anna, Doctor of Science, Research Fellow, Institute of Geosciences, General and Historical Geology

Friedrich Schiller University Jena

Burgweg 11, Jena, 07749 Germany

E-mail:anna.pint@uni-jena.de

ОРИГИНАЛЬНАЯ СТАТЬЯ

УДК 551.583

doi: 10.26907/2542-064X.2021.3.338-350

Палеотемпературы ранней перми: расчет для континентальных красноцветных отложений формации Тамбах в разрезе Бромакер (Нижний красный лежень, Германия)

\author{
Ф. Шольиее, А. Пинт \\ Йенский университет имени Фридриха Шиллера, г. Йена, 07749, Германия
}

\begin{abstract}
Аннотация
Для преобразования данных геохимии в абсолютные значения палеотемператур известно достаточно много формул. В настоящем исследовании проверяется одна из формул расчета палеотемператур ранней перми (артинского яруса), основанная на значениях ключевых элементов из континентальных красноцветных отложений пачки песчаников Тамбах (формация Тамбах, группа
\end{abstract}


Нижний красный лежень) Германии. Геохимические данные взяты из ранее опубликованных работ по исследованию разреза Бромакер. Использование набора данных, основанного на литературных источниках, является новым подходом, направленным на лучшее понимание некоторых палеоклиматических аспектов (средней годовой температуры), характерных для конкретной изучаемой территории, и может применяться в более широких стратиграфических и палеогеографических диапазонах при последующих исследованиях.

Ключевые слова: пермь, артинский ярус, Ротлигенд, климат, температура, красноцветные пласты, Бромакер, Тюрингенский лес

Благодарности. Исследования выполнено при финансовой поддержке Федерального министерства образования и научных исследований, Германия (проект «Бромакер» (Bromacker Project)).

Авторы выражают благодарность Т. Мартенсу за помощь при обследовании наиболее важных участков обнажения пород в окрестностях Тамбах-Дитхарца, а также Й.В. Шнайдеру, С. Фойгту и Б. Гайтч за предоставленные данные по окаменелостям (см. рис. 3, $b$ ). Кроме того, авторы признательны Й.В. Шнайдеру за обсуждение результатов настоящей работы, что позволило во многом ее улучшить.

Поступила в редакцию 24.06.2021

Шольце Франк, доктор наук, научный сотрудник Института геологических наук, общей и исторической геологии

Йенский университет имени Фридриха Шиллера

ул. Бургвег, д. 11, г. Йена, 07749, Германия

E-mail: frank.scholze@uni-jena.de

Пинт Анна, доктор наук, научный сотрудник Института геологических наук, общей и исторической геологии

Йенский университет имени Фридриха Шиллера

ул. Бургвег, д. 11, г. Йена, 07749, Германия

E-mail: anna.pint@uni-jena.de

For citation: Scholze F., Pint A. Early Permian palaeotemperature values proposed for continental red-bed deposits of the Tambach formation at the Bromacker section. Uchenye Zapiski Kazanskogo Universiteta. Seriya Estestvennye Nauki, 2021, vol. 163, no. 3, pp. 338-350. doi: 10.26907/2542-064X.2021.3.338-350.

/ Для цитирования: Scholze F., Pint A. Early Permian palaeotemperature values proposed for continental red-bed deposits of the Tambach formation at the Bromacker section // Учен. зап. Казан. ун-та. Сер. Естеств. науки. - 2021. - Т. 163, кн. 3. - С. 338-350. - doi 10.26907/2542-064X.2021.3.338-350. 